\title{
AMINO ACID STUDIES AND CLINICAL FINDINGS IN NORMAL ADULTS AND RHEUMATOID ARTHRITIS PATIENTS TREATED WITH ACTH ${ }^{1,2}$
}

\author{
By A. L. BORDEN, E. C. BRODIE, E. B. WALLRAFF, W. P. HOLBROOK, D. F. HILL, \\ C. A. L. STEPHENS, JR., R. B. JOHNSON, AND A. R. KEMMERER
}

\author{
(From the Southwestern Clinic and Research Institute, Inc., and The Department of Nutrition, \\ University of Arizona, Tucson, Arizona)
}

(Submitted for publication August 30, 1951; accepted February 5, 1952)

Previous publications from this laboratory (1, 2) have reported that rheumatoid arthritis patients who were treated with ACTH (adrenocorticotrophic hormone) and cortisone (17-hydroxy-11dehydrocorticosterone) exhibited changes in the urinary excretion of certain amino acids. Similar results were found to occur during remission induced by pregnancy $(3,4)$, and one rheumatoid arthritis patient in remission caused by jaundice showed changes even more striking (5). Significant differences have been reported to exist in plasma concentrations of certain "free" amino acids in untreated rheumatoid arthritis patients and in normal individuals (6) . It was considered important, therefore, to determine whether in this disease changes occur in plasma concentrations concomitantly with remission induced by $\mathrm{ACTH}$ therapy and also to establish the effect of ACTH on plasma concentrations and urinary excretion of amino acids in normal adults.

Results for six apparent "free" amino acids in the urinary excretion of normal adults and for seven "free" amino acids in plasma of normal individuals treated with ACTH are compared with those from rheumatoid arthritis patients similarly treated.

\section{METHODS}

The normal control group consisted of four male and four female university students. Immediately before the experiment each student was subjected to a complete physical examination and absence of any disease or obvious metabolic disorder was established. The students

1 This work was supported in part by grants from the United States Public Health Service and the Fair Foundation. ACTH was provided by the Armour Laboratories.

2 A preliminary report of this material was presented before the Federation of American Societies for Experimental Biology, Cleveland, Ohio, April 1951. were not hospitalized but were kept on a closely supervised diet of adequate caloric and vitamin $\mathrm{C}$ intake and one which supplied one gram of protein per kilogram of body weight. The source of protein was the same for all subjects and to that extent the amino acid intake was controlled. Following a three-day control period on the diet, $40 \mathrm{mg}$. of ACTH were administered intramuscularly in three divided doses each day for seven days. Thirtyfive patients were chosen on the basis of an unquestionable diagnosis of rheumatoid arthritis and had been under treatment by the investigators for periods ranging from six months to 15 years. They were hospitalized for observation and study throughout the experiment and were maintained on the same controlled diet as that used for the normal adult group. ACTH was administered intramuscularly in variable dosage of from 40 to $60 \mathrm{mg}$. daily except for one patient who received a much larger dose. It was determined conclusively that the size of the dose had no measurable effect on the plasma levels of the amino acids assayed. In an effort to accelerate or prolong the favorable effects of ACTH therapy some patients included in this study received supplementary medication. During the control period and/or through the treatment period various agents such as ATP (adenosine triphosphate) ascorbic acid, thyroid, testosterone, aspirin, and amino acid feedings were used. None of these supplements altered the significant amino acid increases induced by ACTH.

Twenty-four hour urine specimens were collected on two days prior to the administration of ACTH. During treatment, specimens were collected on alternate days. Aliquots of the samples were stored at $-15^{\circ} \mathrm{C}$.

By using the method of Hier and Bergeim (7), tungstic acid filtrates were prepared from fasting blood samples obtained before and on alternate days of treatment. Filtrates were stored in the frozen state until time of assay. A modification of the microbiological technic of Henderson and Snell (8) was used for the method of assay. Lactobacillus mesenteroides and Streptococcus fecalis $R$ were the test organisms employed. All specimens from one individual were analyzed in one series to eliminate errors due to variations in organism response. The samples were measured in duplicate and at three levels of dilution. In all other details the procedures as previously described $(7,8)$ were followed. In an earlier publication (1) we established that ACTH has no inhibi- 
tory or stimulatory effect on the above mentioned microorganisms. In the same publication it was proven that supplementary medication does not alter the pattern of urinary excretion of amino acids induced by treatment with ACTH. Therefore, patients receiving ACTH with or without supplementary medication were compared to normal adults receiving only ACTH. The effect of supplementary medication on amino acid values in the plasma is discussed later. The results shown in this paper were statistically analyzed by the Multiple Variance Method (9) and the Student's $t$ Test (10).

\section{RESULTS}

\section{Clinical}

The clinical findings in the group of rheumatoid arthritis patients were the same as those reported in one of our earlier publications (1).

Interestingly enough the group of normal adults did not experience the findings manifested by the patients with the disease. There was no increase in appetite, no indication of insomnia, no increase in energy, nor any measurable change in mental alertness. Weight was maintained at a relatively constant level throughout the experiment. There were no indications of toxicity. In short, upon careful examination it was impossible to detect any difference in the way the normal adults reacted before beginning the medication and during its administration.

\section{Chemical}

Urine: In Table I the comparison is made between the urinary excretion of six apparent "free" amino acids in rheumatoid arthritis patients and normal adults treated with ACTH. The response to the medication gives a "curve" type reaction in which excretion values rise to a "peak" or maximum level and, while medication is still being administered, gradually level off. All treatment values, however, are well above control levels established before institution of therapy. Previous work $(1,2)$ reported that in rheumatoid arthritis patients treated with $\mathrm{ACTH}$, the average and maximum 24-hour excretion of histidine, lysine, threonine, and tyrosine showed a $1 \%$ significant increase. In the normal adults the urinary excretion of none of the above mentioned amino acids was significantly increased with the exception of threonine for which there was a significant $5 \%$ increase at the maximum level only. Phenylalanine and tyrosine were increased at the $1 \%$ significant level but only at the time of maximum excretion. The degree of response to ACTH was significantly less in the urinary excretion of normal adults than in patients with rheumatoid. arthritis. The single exception was phenylalanine where the reverse was true at the maximum level. In neither group was the excretion of arginine altered. Tyrosine

TABLE I

Average and maximum 24-hour urinary excretion of six apparent "free" amino acids in rheumatoid arthritis patients and in normal adults treated with $A C T H$

\begin{tabular}{|c|c|c|c|c|c|}
\hline Amino acid & Type subject & No. & $\begin{array}{l}\text { Before treatment } \\
\text { (mean) }\end{array}$ & $\begin{array}{l}\text { During treatment } \\
\text { (average mean) }\end{array}$ & $\begin{array}{l}\text { During treatment } \\
\text { (maximum) }\end{array}$ \\
\hline Arginine & $\begin{array}{l}\text { Arthritis } \\
\text { Normal }\end{array}$ & $\begin{array}{r}31 \\
8\end{array}$ & $\begin{array}{l}m s . / 24 \mathrm{kr} . \\
5.8 \pm 1.30 \\
8.3 \pm 0.74\end{array}$ & $\begin{array}{c}m g . / 24 \mathrm{hr} . \\
6.1 \pm 1.0 \\
10.0 \pm 0.84\end{array}$ & $\begin{array}{c}m g . / 24 \mathrm{hr} . \\
8.3 \pm 1.28 \\
11.3 \pm 0.94\end{array}$ \\
\hline Histidine & $\begin{array}{l}\text { Arthritis } \\
\text { Normal }\end{array}$ & $\begin{array}{r}31 \\
8\end{array}$ & $\begin{array}{r}58.0 \pm 6.91 \\
137.0 \pm 14.14\end{array}$ & $\begin{array}{l}126.0 \pm 12.42 * \dagger \\
174.0 \pm 15.57\end{array}$ & $\begin{array}{l}169.0 \pm 16.85 * \dagger \\
195.0 \pm 16.65 \ddagger\end{array}$ \\
\hline Lysine & $\begin{array}{l}\text { Arthritis } \\
\text { Normal }\end{array}$ & $\begin{array}{r}31 \\
8\end{array}$ & $\begin{array}{l}21.4 \pm 2.24 \\
23.4 \pm 7.00\end{array}$ & $\begin{array}{l}46.7 \pm 5.78^{*} \dagger \\
25.2 \pm 8.19\end{array}$ & $\begin{array}{l}67.2 \pm 8.48^{*} t \\
32.0 \pm 8.52\end{array}$ \\
\hline Phenylalanine & $\begin{array}{l}\text { Arthritis } \\
\text { Normal }\end{array}$ & $\begin{array}{r}12 \\
8\end{array}$ & $\begin{array}{l}7.3 \pm 0.95 \\
9.8 \pm 0.76\end{array}$ & $\begin{array}{l}11.4 \pm 1.66 \\
12.3 \pm 0.32 \ddagger\end{array}$ & $\begin{array}{l}15.5 \pm 3.07 \ddagger \\
13.3 \pm 0.32\end{array}$ \\
\hline Threonine & $\begin{array}{l}\text { Arthritis } \\
\text { Normal }\end{array}$ & $\begin{array}{r}31 \\
8\end{array}$ & $\begin{array}{l}16.6 \pm 2.98 \\
17.2 \pm 1.13\end{array}$ & $\begin{array}{l}43.7 \pm 7.57^{*} \dagger \\
23.2 \pm 2.52 \ddagger\end{array}$ & $\begin{array}{l}65.2 \pm 12.38^{*} \dagger \\
26.3 \pm 2.29 \ddagger\end{array}$ \\
\hline Tyrosine & $\begin{array}{l}\text { Arthritis } \\
\text { Normal }\end{array}$ & $\begin{array}{r}20 \\
8\end{array}$ & $\begin{array}{l}19.7 \pm 2.23 \\
12.3 \pm 0.89\end{array}$ & $\begin{array}{l}32.3 \pm 3.17^{*} \dagger \\
14.7 \pm 1.26\end{array}$ & $\begin{array}{l}43.2 \pm 4.06^{*} \dagger \\
17.4 \pm 1.14 \ddagger\end{array}$ \\
\hline
\end{tabular}

* Significant at the 1\% level (Analysis of Variance).

+ Significantly different from normal at $1 \%$ level ( $t$ Test).

\$ Significant at the $5 \%$ level (Analysis of Variance). 


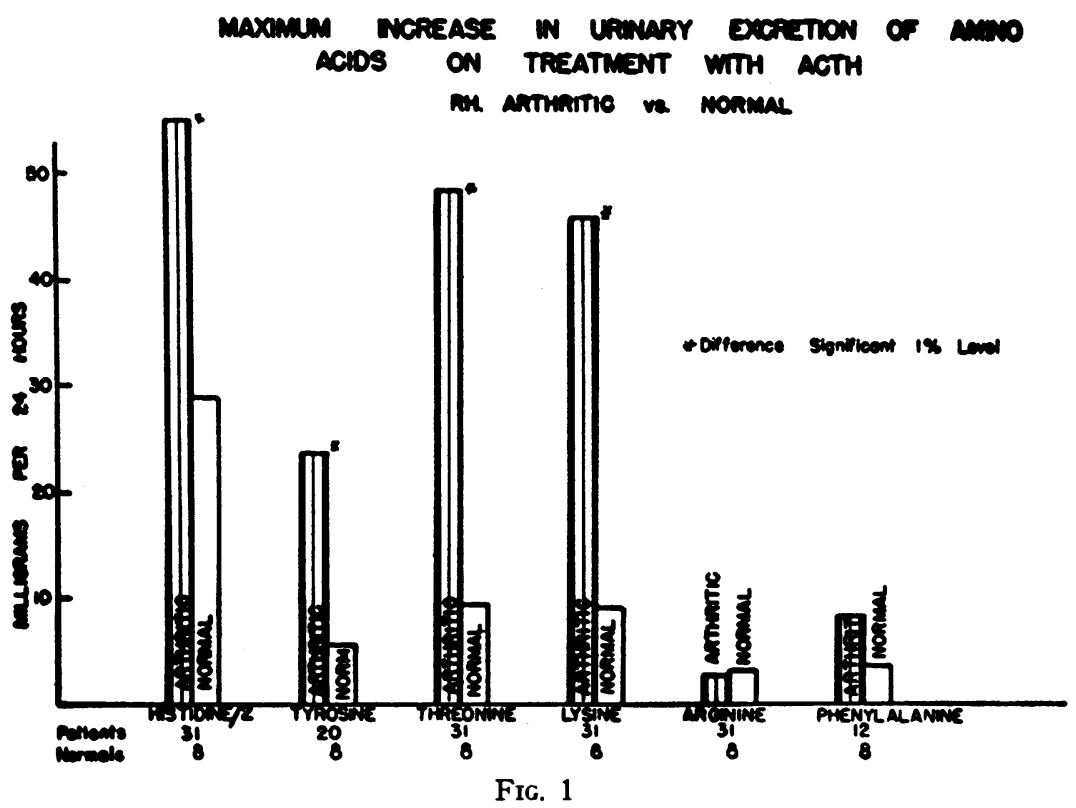

and histidine values before treatment are signifi- in the plasma estimations. As seen in Table II, cantly different for normal individuals and pa- at the maximum plasma concentrations observed tients with the disease. The maximum increases during treatment, the group of rheumatoid arin urinary excretion of amino acids in the two treated groups are shown in Figure 1.

Plasma: The same "curve" type response which was noted in the urinary excretions occurred also thritis patients showed a significant increase for each of the seven amino acids. The average values during treatment were increased significantly for arginine, lysine, and threonine.

TABLE II

Average and maximum plasma concentrations for seven apparent "free" amino acids in rheumatoid arthritis patients and normal adults treated with ACTH

\begin{tabular}{|c|c|c|c|c|c|}
\hline Amino acid & Type subject & No. & $\begin{array}{l}\text { Before treatment } \\
\text { (mean) }\end{array}$ & $\begin{array}{l}\text { During treatment } \\
\text { (average mean) }\end{array}$ & $\begin{array}{l}\text { During treatment } \\
\text { (maximum) }\end{array}$ \\
\hline Arginine & $\begin{array}{l}\text { Arthritis } \\
\text { Normal }\end{array}$ & $\begin{array}{r}35 \\
8\end{array}$ & $\begin{array}{l}\text { gamma/ml. } \\
13.8 \pm 1.33 \\
15.0 \pm 0.90\end{array}$ & $\begin{array}{l}\text { gamma } / \mathrm{ml} \\
17.5 \pm 1.71 \mathrm{ft} \\
15.5 \pm 0.84\end{array}$ & $\begin{array}{l}\text { gamma/ml. } \\
19.4 \pm 1.98 * \dagger \\
17.2 \pm 1.04\end{array}$ \\
\hline Histidine & $\begin{array}{l}\text { Arthritis } \\
\text { Normal }\end{array}$ & $\begin{array}{r}34 \\
8\end{array}$ & $\begin{array}{l}11.0 \pm 0.71 \\
14.2 \pm 0.86\end{array}$ & $\begin{array}{l}11.9 \pm 0.80 \\
12.8 \pm 0.96\end{array}$ & $\begin{array}{l}13.3 \pm 0.99 \ddagger \\
14.0 \pm 1.02\end{array}$ \\
\hline Lysine & $\begin{array}{l}\text { Arthritis } \\
\text { Normal }\end{array}$ & $\begin{array}{r}35 \\
8\end{array}$ & $\begin{array}{l}27.9 \pm 2.01 \\
26.1 \pm 1.96\end{array}$ & $\begin{array}{l}34.5 \pm 2.311^{*} \dagger \\
24.1 \pm 1.42\end{array}$ & $\begin{array}{l}38.7 \pm 2.69^{*} \dagger \\
26.9 \pm 1.80\end{array}$ \\
\hline Phenylalanine & $\begin{array}{l}\text { Arthritis } \\
\text { Normal }\end{array}$ & $\begin{array}{r}20 \\
8\end{array}$ & $\begin{array}{l}12.1 \pm 0.52 \\
10.9 \pm 0.61\end{array}$ & $\begin{array}{l}12.9 \pm 0.54 \\
11.3 \pm 0.40\end{array}$ & $\begin{array}{l}15.1 \pm 0.86^{*} \dagger \\
12.1 \pm 0.48\end{array}$ \\
\hline Proline & $\begin{array}{l}\text { Arthritis } \\
\text { Normal }\end{array}$ & $\begin{array}{r}13 \\
8\end{array}$ & $\begin{array}{l}21.6 \pm 1.77 \\
29.4 \pm 2.17\end{array}$ & $\begin{array}{l}24.9 \pm 1.93 \\
30.4 \pm 2.74\end{array}$ & $\begin{array}{l}29.2 \pm 2.39^{*} \\
33.4 \pm 2.40\end{array}$ \\
\hline Threonine & $\begin{array}{l}\text { Arthritis } \\
\text { Normal }\end{array}$ & $\begin{array}{r}35 \\
8\end{array}$ & $\begin{array}{l}12.9 \pm 1.2 \\
13.4 \pm 1.15\end{array}$ & $\begin{array}{l}17.9 \pm 0.97 * \dagger \\
13.8 \pm 0.42\end{array}$ & $\begin{array}{l}20.4 \pm 1.29 * t \\
15.4 \pm 0.41\end{array}$ \\
\hline Tyrosine & $\begin{array}{l}\text { Arthritis } \\
\text { Normal }\end{array}$ & $\begin{array}{r}18 \\
8\end{array}$ & $\begin{array}{r}13.9 \pm 0.96 \\
9.8 \pm 0.79\end{array}$ & $\begin{array}{c}14.6 \pm 1.12 \dagger \\
9.6 \pm 0.71\end{array}$ & $\begin{array}{l}17.2 \pm 1.37 \dagger \ddagger \\
10.4 \pm 0.87\end{array}$ \\
\hline
\end{tabular}

* Significant at the 1\% level (Analysis of Variance).

+ Significantly different from normal at $1 \%$ level $(t$ Test).

$\mp$ Significant at the $5 \%$ level (Analysis of Variance). 


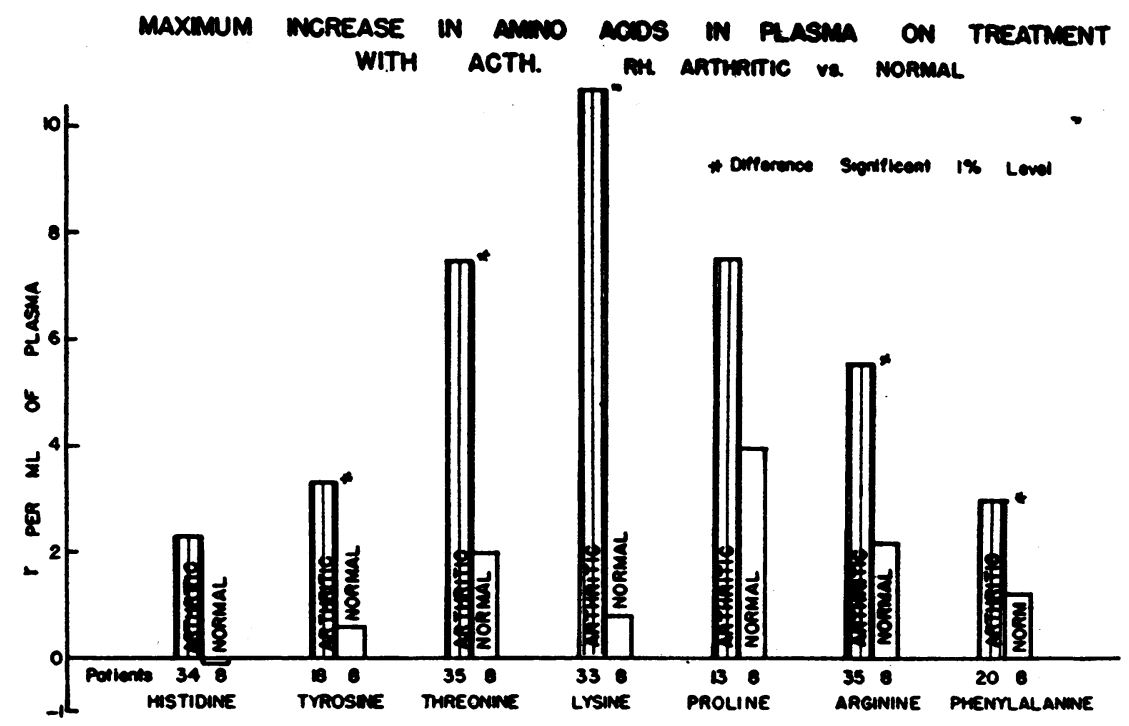

FIG. 2

While the plasma values for the group of normal individuals showed the same general trend as the rheumatoid arthritis patients, the changes observed, both at the time of maximum increase and at the average level, were not significantly increased over the control values obtained before treatment.

The behavior of the treated rheumatoid arthritis group as compared with the group of normal adults was significantly different in several instances. At the maximum plasma response the difference in the way the groups reacted was highly significant for arginine, lysine, phenylalanine, threonine, and tyrosine. The maximum value response was not significantly different for histidine or proline. The average treatment plasma values for the two groups were significantly different at the $1 \%$ level for arginine, lysine, threonine, and tyrosine and not significantly altered for histidine, phenylalanine, or proline. The maximum increases in plasma amino acids for the two groups treated with ACTH are shown in Figure 2.

Our own investigations, as well as the work of others (11), have established that plasma values for the amino acids are relatively constant in an individual. It seems, therefore, that these significant differences due to therapy with ACTH are worthy of consideration. The small but significant plasma increases, when considered in terms of total circulating blood volume, indicate an appreciable change.
By means of an analysis with the Multiple Variance Test (9), the results from patients with rheumatoid arthritis treated simultaneously with supplementary medication and ACTH were compared with those from the group whose treatment was uncomplicated. It was conclusively proven that those plasma amino acid concentrations which were significantly increased by ACTH therapy were not significantly affected by supplementary medication.

\section{DISCUSSION}

We have no adequate explanation for the changes in amino acid concentrations in plasma levels and in urinary excretions. A number of possibilities have been considered to explain the mechanism at work but we have as yet no actual proof to substantiate them. All indications are that we are measuring changes in intrinsic protein metabolism. Although the mechanism of amino aciduria is not understood, a lowered renal threshold does not appear to be involved. Tolerance tests with histidine and threonine, now in progress in this laboratory, have shown that even when an oral dose of from 2 to 10 grams is employed, only $2 \%$ to $5 \%$ of the amino acid is recovered in the urinary excretion (12).

It is interesting to note that the urinary excretion of arginine is not increased in either group while the plasma levels for arginine in the rheumatoid arthritis group are significantly increased. 
Of further interest is the fact that the value for histidine, the amino acid excreted in such large amounts in the urine in remissions induced by pregnancy, jaundice, cortisone, or $\mathrm{ACTH}$, is not altered to a large degree in the plasma.

Because the data here presented show such significant differences between the reactions of the two groups to ACTH therapy, additional evidence seems provided of a correlation between amino acid metabolism and the remission factor in rheumatoid arthritis.

\section{SUMMARY}

In a group of normal individuals treated with ACTH, microbiological assays for six "free" amino acids were determined on 24-hour urine samples, and for seven amino acids on plasma filtrates. The values have been compared with those found in rheumatoid arthritis patients similarly treated.

Unlike the clinical findings in patients with rheumatoid arthritis, the treated normal adults manifested no improvement in appetite, increased energy, mental alertness, or sense of general wellbeing.

Urinary excretion and plasma values for the rheumatoid arthritis group exhibited appreciable increases during the treatment with ACTH. The most significant changes occurred for histidine, lysine, threonine, and tyrosine in the urine, and for arginine, lysine, and threonine in the plasma.

The results for the normal adults followed the same general trend in response but to a strikingly less degree. In the urinary findings only phenylalanine and tyrosine were significantly increased during treatment and then only at the time of maximum excretion. None of the plasma amino acids assayed was significantly increased at any time during the treatment.

A highly significant difference in amino acid response of the two groups occurred for histidine, lysine, threonine, and tyrosine in the urine, and for arginine, lysine, threonine, and tyrosine in the plasma. It is interesting to note that the histidine changes are limited to the urinary excretion findings while the arginine changes are peculiar to the plasma.

\section{ACKNOWLEDGMENTS}

The authors wish to express their appreciation to Dr. M. G. Vavich for his criticisms and suggestions and to Mr. Joel E. Fletcher for his valuable help with the statistical analyses and charts. Further appreciation is extended to the group of students for their excellent cooperation in making this study possible.

\section{REFERENCES}

1. Stephens, C. A. L., Jr., Wallraff, E. B., Borden, A. L., Brodie, E. C., Holbrook, W. P., Hill, D. F., Kent, L. J., and Kemmerer, A. R., Apparent free histidine plasma and urine values in rheumatoid arthritis treated with cortisone and ACTH. Proc. Soc. Exper. Biol. \& Med., 1950, 74, 275.

2. Brodie, E. C., Wallraff, E. B., Borden, A. L., Holbrook, W. P., Stephens, C. A. L., Jr., Hill, D. F., Kent, L. J., and Kemmerer, A. R., Urinary excretion of certain amino acids during ACTH and cortisone treatment of rheumatoid arthritis. Proc. Soc. Exper. Biol. \& Med., 1950, 75, 285.

3. Unpublished data.

4. Wallraff, E. B., Brodie, E. C., and Borden, A. L., Urinary excretion of amino acids in pregnancy. J. Clin. Invest., 1950, 29, 1542.

5. Borden, A. L., Wallraff, E. B., Brodie, E. C., Holbrook, W. P., Hill, D. F., Stephens, C. A. L., Jr., Johnson, R. B., and Kemmerer, A. R., Effect of adrenocorticotrophic hormone on amino acid content of blood and urine in normal individuals and patients with rheumatoid arthritis. Federation Proc., 1951, 10, 376.

6. Borden, A. L., Wallraff, E. B., Brodie, E. C., Holbrook, W. P., Hill, D. F., Stephens, C. A. L., Jr., Kent, L. J., and Kemmerer, A. R., Plasma levels of free amino acids in normal subjects compared with patients with rheumatoid arthritis. Proc. Soc. Exper. Biol. \& Med., 1950, 75, 28.

7. Hier, S. W., and Bergeim, O., Microbiological determination of free leucine, isoleucine, valine, and threonine in dog plasma. J. Biol. Chem., 1945, 161, 717.

8. Henderson, L. M., and Snell, E. E., A uniform medium for determination of amino acids with various microorganisms. J. Biol. Chem., 1948, 172, 15.

9. Snedecor, G. W., Statistical Methods Applied to Experiments in Agriculture and Biology. Collegiate Press, Inc., Ames, Iowa, 1946, Ed. 4, Section 10.4.

10. Snedecor, G. W., Ibid., Section 3.8.

11. Kirsner, J. B., Sheffner, A. L., and Palmer, W. L., Studies on amino acid excretion in man. III. Amino acid levels in plasma and urine of normal men fed diets of varying protein content. J. Clin. Invest., 1949, 28, 716.

12. Unpublished data. 